\title{
The Effects of Service Innovation on Perceived Value and Guest's Return Intention - A Study of Luxury Hotels in Ho Chi Minh City, Vietnam
}

\author{
Mai Ngoc Khuong and Tran Huong Giang
}

\begin{abstract}
This research aimed to explore factors affecting to service innovation and how well the influence of innovative practices on the way guests perceiving value and their intention to return the hotels. Quantitative research approach was applied with convenient sampling technique and a completed set of well-structured questionnaires was delivered directly to 300 respondents who were foreign tourists staying at three to five-star hotels in Ho Chi Minh City, Vietnam. This study found that marketing-focused innovation, process innovation, price innovation, hotel types, customization of service, and use information technology were positively correlated with guest's return intention. In addition, the empirical results showed that factors of pricing innovation, process innovation and hotel types provided both indirect and indirect effects towards the return intention.
\end{abstract}

Index Term-Hotel types, process innovation, marketing-focused innovation, pricing innovation, perceived value, guest return intention.

\section{INTRODUCTION}

In the 21st century, Vietnam has been being integrated into global economy and become one of the attractive tourist destinations in the Asia-Pacific region, which results in Vietnam's tourism industry to recently has a strong tendency to develop. In 2009, despite facing economic crisis global tourism industry was estimated to contribute $13.1 \%$ of Total Gross Domestic Product (GDP) for the economy of Vietnam. In 2012, Vietnam welcomed 6.84 million foreign visit turns (higher 60.98 percent compared with 2008) and 32.5 million domestic visit turns [1]. The incessant growth of tourism creates favorable opportunities to hotel services industry and activities related to this sort of service also become more dynamic and profitable. Nevertheless, the appearance of so many hotels causes the market of this service to become more intensely competitive. Therefore, building sustainable competitive advantage for organizations has become an important consideration. To increase capacity of competition, many hotels have also been looking for the way to develop a continuing innovate environment in order to respond the competitive market of globalization and meet the higher

Manuscript received June 13, 2014; revised August 15, 2014.

Mai Ngoc Khuong and Tran Huong Giang are with the School of Business, International University -VNU-HCM, Vietnam (e-mail: mnkhuong@hcmiu.edu.vn, huonggiangtran10153@gmail.com). demand of both domestic and foreign tourists. As a result, the concept of service innovation is defined. Service innovation plays an important role in hotel management because it creates service differentiation and induces financial gains, which promotes managers to implement innovations to desire customers and bring economically benefits to the companies [2]. Service innovation is virtually considered as lodestar in hospitality management because it creates service differentiation, enhances the hotel's competitive capacity and attracts more customers. On the other hands, application or implementation innovation in business is not simple and easy at all. It substantially requires ideas, practices and skills in order to be innovative [3]. In reality, however, innovation in service has not been acknowledged effectively applied by hotel organizations in Vietnam.

Previously, there have been many researches focusing on the positive impacts of sustainable competitive advantage of innovation in the field of manufacturing industry. Relatively, few researches make considerable concern on the competitive advantage, productivity and economic growth of the enterprise in hospitality industry of Vietnam context. Therefore, it seems to be not clear for the service innovation application and its effectiveness of these organizations.

Apart from competition among the same rank of hotel, these luxury hotel establishments have been recently facing with many difficulties because of appearance of other types of accommodation establishments, such as guest house, dormitory and hostel. In reality, tourists usually stay at luxury hotels for the first time of visiting Ho Chi Minh City, but cheaper-price accommodation would be their prior choice if they return back the city. This is explicated by two following reasons. The first one is that travellers who plan to visit Vietnam for a long time, of course, a normal hotel with cheap price is more appropriate with them. But this study is inclined to the second explanation, which is that the guest does not really perceive the difference of service value between the two groups of hotel.

It is acknowledged that luxury hotels offer good service and the price could not be as cheap as a guest house or a hostel. But, the important thing is how to induce the guest to recognize that service provided of such hotels is completely equivalent with their payment. Price for staying at a five-star hotel is regularly considered as expensive expenditure. Therefore, it is important to make these guests be aware that what they paid is totally worthy with what they are offered by the services. Consequently, innovation in service is a key factor for resolving such issues and attaining organization development. 


\section{LITERATURE REVIEW}

\section{A. Service Innovation}

Innovation, therefore, is defined as an idea, practice, or object that is recognized as novelty by an individual or other unit of adoption [3]. Innovation is considered as competitive advantage that organizations should achieve in order to certainly stay ahead with their fierce competitors. Most managers believe that innovations not only create additional value to their customer but also are economically viable to the firms [4]. Service innovation is conceptualized as service concept, client interaction channel, service delivery system or technological concept that is new or considerably changed individually. Furthermore, a combination of such modification could also lead to one or more service functions that are new to the firm as well as the market [5].

There are many studies and literatures available to support the factors affecting service innovation. Service industry generally is defined to covers a wide scope of activities and industry. Nevertheless, this study mainly focuses on the hospitality industry which only specializes in luxury hotels that forming a significant part of the industry.

Hotel types: Innovation in service involves the introduction of new services as well as modification of existing service [6]. This term was developed to be a source of innovative service [7]. An excellent example of innovative service in term of hotel type is emergence of a so-called Boutique hotel which is believed to have been designed in the early 1980s. Hotel guests have tendency to perceive boutique hotel as a stylish place where they are willing to pay premium room rates [8]. Apart from boutique hotels, with unfavorably changes of the climate and environment due to extracting and industrial activities, many customers tend to highly appreciate and pursue environmentally friendly products as well as services [9]. Catching up with that demand, the "green" hotel business is also a growing niche market to differentiate itself from other hospitality industries. The hotel industry has been a leading sector in the development of more environmentally friendly operational management practices [10]. Additionally, the model of hotels combined with M.I.C.E (Meeting Incentive Conference Event) have been recently become a compelling idea for innovative service offerings in hotel industry due to the participation and agreement in WTO and APEC. The last type of hotel that is emerged in recent years is healthy-style hotel which is defined as a hotel facilitated additional conditions such as up-to-date fitness centers, swimming pools, spa, etc. with the purpose of serve guests' sport demands.

Customization of service: Mass customization is asserted as use of flexible processes and organizational structures to produce variety and often individually customized products and services at the low cost of a standardized, mass production system [11]. Flexibility of check in or check out times, allowance to personalizing rooms decor, provision child care options, allowance small pets in rooms are examples of customization of service [7].

Use of information technology: The term implies firm's ability to adopt new software, integrated systems and technology, and an ability to innovate with software and technology in order to keep ahead of the market [12].
Information technology diffusion in the tourism and hospitality industries has recently increased at an unprecedented rate [13].

Process innovation: Innovation in processes refers to innovations made in processes with respect to preparation and presentation of the service to the clients. These processes highly play an important role in terms of presenting services in accurate and high quality manner. Innovation to be performed in service processes can significantly contribute to "the way the service is presented by employees", which is called "the functional quality of service" [14].

Marketing-focused innovation: Focusing on marketing activities is also a source of service innovation in hotel industry. Marketing-focused innovation capability refers to ability of firms to develop and implement novel promotional approaches, and an ability to implement innovative marketing programs for its services and products in order to keep ahead of the market [15]. Specifically, promotion factor directly affects to occupancy rate of hotel. In other words, promotion is marketing strategies designed to pull the market (customers) to the hotel and its services [16].

Brand differentiation: Brand differentiation is one of nine drivers for service innovation [17]. This concept was used as a variable named "Brand Image" to explore its effect on service innovation. Brand image is one of aspects composing brand equity as it conveys the worth of the brand to the consumers. Brand image is perception of customers about a brand, as reflected by the brand associations held in customer memory. Hotel firms consider building strong brand as "a quick way to identify and differentiate themselves in the minds of the customers, serving as a signature of the hotel chain, its products, and services" [18].

Pricing innovation: The importance of price is confirmed as a key dimension in hotel selection. One of the most important aspects of hotel strategies is room price as it is one of the main influences in the customer purchase decision [19]. In most companies, however, the pricing function receives limited attention whereas this area is highly concerned by some industries such as hospitality, airlines, health care and pharmaceutical [20]. Innovation in pricing strategy illustrates how companies implement innovative pricing strategies, such as customer value-based pricing. Pricing innovation strategy deals with innovative tools to measure and increase customer willingness to pay and to communicate value to the guest.

\section{B. Perceived Value}

Perceived value is defined as "the customer's overall assessment of the utility of a product based on perceptions of what is received and what is given" [21]. Perceived value is measured in both time and price, through the perceived utility or worth which resulting from the tradeoff between "get" and "give-up" [21], [22]. Perceived value is one of the most important constructs for an organization seeking to gain a competitive edge [23].

\section{Guest Return Intention}

Behavioral intention represents the repurchase intentions, word of mouth, loyalty complaining behavior, and price sensitivity [21]. The term of repurchase intention is usually used for manufacturing products whereas hospitality industry 
prefers to use the term of guest's return intention. Repurchase intention or return intention is the individual's judgment about buying again a designated service from the same company [24]. Retaining guests with their intention to return is one of the most important tasks to be carefully considered by successful organizations.

The literature identifies the following sub-dimensions as components of service innovation: Hotel Type, Customization of Service, Use of Information Technology [7], Process Innovation [14], Marketing-focused Innovation [15], Brand differentiation [17] and Pricing Innovation [19]. These seven factors accompanied with perceived value and guest return intention as elements to develop the conceptual model. The following hypotheses were proposed for relationship among observed variables of this study:

- H1: Factors of service innovation directly affect perceived value.

- H2: Factors of service innovation directly affect guest's return intention.

- H3: Guest's return intention is directly affected by perceived value.

- H4: Factors of service innovation indirectly affect guest's return intention through perceived value.

\section{Methodology}

\section{A. Research Design and Data Collection}

This research's purpose was to test the hypothesis of effects of service innovation on perceived value and intention to return of guests based on some theories mentioned in literature review; quantitative approach was chosen to be used. In terms of research techniques, communication study (survey) was applied to gather primary data and assess the research questions for this study.

This research was designed to gain understanding how service innovation affected to perceived value and guest's return intention in luxury hotel industry. Structured questionnaire were delivered directly to 300 foreign tourists who were stayed at luxury hotels (three, four and five-star hotels) for reasons of business and leisure in Ho Chi Minh City.

\section{B. Exploratory Factor Analysis}

In this study, the self-administered questionnaire was designed to measure the perceived value and return intention of guests affected by factors of service innovation. The questionnaire consisted of two main parts. In the first part, perceived value and guest's return intention belonged to dependent variables with 12 items and seven factors of service innovation were independent variables which based on a five-point Likert scale in which 1 was "strongly disagree" and 5 was "strongly agree". To measure service innovation, seven dimensional scales (hotel types, use of information technology, customization of service, process innovation, marketing-focused innovation, brand image, and pricing innovation with 37 items were used.

With the purpose of testing validity of the scales, exploratory factor analysis (EFA) was applied. After conducting the EFA test, group of dependent variables included two dimensions (PERVA as perceived value and
GURETINT as guest's return intention) with 11 items and the Kaiser-Meyer-Olkin measure was .880. For independent ones, origin 37 items were reduced to 23 items distributed in six components with .836 as value of the Kaiser-Meyer-Olkin. They were renamed as MAFOCIN, PROCIN, PRICE, HOTYPE, CUSOFSER and USOFINTE. Specifically, MAFOCIN presents as Marketing-focused innovation, PROCIN as Innovation in process, PRICE as Pricing innovation, HOTYPE as Hotel types, CUSOFSER as Customization of service and USOFINTE as Use of information technology, as shown in table II. Then, reliability testing was conducted to evaluate the degree of consistency among items. For dependent variables perspective, the Cronbach's alpha value of PERVA attained .848 , while the internal consistency of items in GURETINT is .837, as shown in Table I.

TABLE I: THE SUMMARY OF DEPENDENT VARIABLES

\begin{tabular}{lcc}
\hline \hline Given Names & $\begin{array}{c}\text { Number of } \\
\text { Items }\end{array}$ & Alpha \\
\hline Perceived Value (PERVA) & 6 & .848 \\
\hline Guest Return Intention (GURETINT) & 5 & .837 \\
\hline \hline
\end{tabular}

Cronbach's alpha reliability coefficient for independent variables scale was measured and the reliability coefficients were found as .876, .840, .801, .773, .766 and .696 for MAFOCIN, PROCIN, PRICE, HOTYPE, CUSOFSER and USOFINTE, respectively, as shown in Table II.

TABLE II: THE SUMMARY OF INDEPENDENT VARIABLES

\begin{tabular}{lcc}
\hline \hline Given names & $\begin{array}{c}\text { Number } \\
\text { of Items }\end{array}$ & Alpha \\
\hline Marketing-focused Innovation (MAFOCIN) & 5 & .876 \\
\hline Process Innovation (PROCIN) & 5 & .840 \\
\hline Pricing Innovation (PRICE) & 3 & .801 \\
\hline Hotel Types (HOTYPE) & 4 & .773 \\
\hline Customization of Service (CUSOFSER) & 2 & .766 \\
\hline Use Information Technology (USOFINTE) & 4 & .696 \\
\hline \hline
\end{tabular}

\section{Findings AND AnAlysis Results}

\section{A. Demographic Characteristics of Respondents}

The object of this research was luxury three to five-star hotels. Among 300 qualified respondents, $45.7 \%$ of them were male while $54.3 \%$ were female. In the aspect of age, the age category of 18 to 25 years old and $25-30$ years old were approximately the same each other, $33 \%$ and $32.7 \%$, respectively. There was no respondent aged less than 18 years old. The group of age from 31 to 40 accounted for $17.7 \%$. There were $14.3 \%$ of them are between 41 and 60 years old and only $2.3 \%$ of them were more than 60 years old. From the statistics, it seemed that the younger people had tendency to travel more than the older. Regarding nationality, majority of the visitors came from Europe which accounted for $67.7 \%$ and the rest of them in descending order were Australian and New Zealander (10.3\%); American and Canadian (9.3\%); Asian (9\%). Only $0.7 \%$ respondents were from Latin America and the remaining travellers were Russian and African, which occupied 3\%. Regarding to education aspect, master and higher degree accounted for the 
highest percentage of 30.3. This was followed by bachelor degree with $29.7 \%$, studying university with $12.3 \%$, college degree with $13 \%$ and high-school degree with $14.7 \%$. Visitors travelling for their leisure and holiday occupied the highest percentage $(79.7 \%)$ compared to the purpose of travelling to Vietnam for doing business and visiting their friends or family $(8.7 \%$ and $6.7 \%$, respectively).

\section{B. Correlations between Service Innovation and GURETINT}

TABLE III: THE CORRELATIONS BETWEEN VARIABLES

\begin{tabular}{lccccccc}
\hline \hline & GURETINT & 1 & 2 & 3 & 4 & 5 & 6 \\
\hline 1. MAFOCIN & $.301^{* *}$ & 1 & & & & & \\
2. PROCIN & $.433^{* *}$ & $.361^{* *}$ & 1 & & & & \\
3. HOTYPE & $.377^{* *}$ & $.239^{* *}$ & $.362^{* *}$ & 1 & & & \\
4. PRICE & $.430^{* *}$ & $.307^{* *}$ & $.416^{* *}$ & $.290^{* *}$ & 1 & & \\
5. USOFINTE & $.145^{*}$ & $.407^{* *}$ & $.362^{* *}$ & $.292^{* *}$ & $.167^{* *}$ & 1 & \\
6. CUSOFSER & $.262^{* *}$ & $.349^{* *}$ & $.399^{* *}$ & $.370^{* *}$ & $.255^{* *}$ & $.410^{* *}$ & 1 \\
7. PERVA & $.582^{* *}$ & $.244^{* *}$ & $.487^{* *}$ & $.343^{* *}$ & $.621^{* *}$ & $.189^{* *}$ & $.245^{* *}$ \\
\hline \multicolumn{1}{c}{ Mean } & 3.44 & 3.10 & 3.61 & 3.36 & 3.81 & 3.38 & 3.15 \\
\hline \multicolumn{1}{c}{ SD. } & .752 & .765 & .633 & .715 & .767 & .835 & .994 \\
\hline \hline
\end{tabular}

Table III illustrated the correlation coefficients between six independent variables and dependent variables. In this bivariate correlation testing, two-tailed test was applied to test whether these variables were positively or negatively related. Two independent variables with a bivariate correlation more than 0.7 should be omitted because of possibility of causing multicollinearity [25]. This problem refers to the excessive correlation of the independent variables. The highest correlation value was 0.416 , which was less than 0.7. So, all factors would be retained. For the correlation between independent and dependent variables, there was a relatively strongly positive correlation PRICE and PERVA $(r=.621, p<.01)$. Next, PROCIN variable was also strongly positively correlated with PERVA $(r=.487$, $p<.01)$. The four remaining factors which were MAFOCIN, HOTYPE, USOFINTE and CUSOFSER had average positive correlation with PERVA as $0.244,0.343,0.189$ and 0.245 , respectively with p-values for all are less than .01 . The Pearson correlation analysis results indicated that each of six independent variables had positive association with GURETINT variable. In these relationships, there were relatively strong positive correlations between PROCIN and GURETINT $(r=.433, p<.01)$ and between PRICE and GURETINT $(r=.430, p<.01)$. This showed that the better pricing innovation was practiced and the better the service delivery system and the qualification of the staffs were, the more the guests intended to return the hotel. Besides that, the variables of HOTYPE, MAFOCIN, and CUSOFSER were positively related with dependent variable of GURETINT with the correlation coefficient in turn as .377, .301, .262, and the correlation testing of those variables was statistically significant with $p<.01$. USOFINTE had a low positive relationship with GURETINT $(r=.145, p<.05)$. This indicated that the available of high information technology implementation of hotel poorly affected to the guest's intention to return the hotel. As the results from the Table III, the correlation coefficient between PERVE and GURETINT was equal to .582 , which concluded that the two dependent variables were strongly positively associated with each other. This meant that the higher perceived value the guest perceived, the more likely they intended to return the hotel for the second time.

\section{Direct Effect of Perceived Value}

Hypothesis 1 was tested with the results shown on the standardized coefficients in Table IV, PERVA was directly affected by three variables of service innovation which were PRICE (Pricing Innovation) with $(\beta=.492, p<.01)$, PROCIN (Process Innovation) with $(\beta=.255, p<.01)$ HOTYPE (Hotel Types) with $(\beta=.120, p<.05)$. This revealed that pricing innovation made the strongest contribution to explaining the perceived value variable. Adjusted R Square was checked with the value of 0.45 . This meant that the model with six independent variables (MAFOCIN, PROCIN, HOTYPE, PRICE, USOFFINTE and CUSOFSER) could explain $45 \%$ variance of dependent variable (PERVA).

\section{Direct Effects of Guest's Return Intention \\ 1) Service innovation and guest's return intention}

Hypothesis 2 was tested by conducting multiple regression analysis. The Significant index indicated that, USOFINTE and CUSOFSER failed to achieve statistical significance in order to have effect on GURETINT (Guest's Return Intention) with Sig. was equal to $.066>.05$ and $.643>.05$, respectively. With the Sig. value less than .05 , the four independent variables consisting of MAFOCIN, PROCIN, HOTYPE, PRICE directly affected to GURETINT. Pricing innovation had the most positive important influences to guest's return intention with the standardized Beta $(\beta)$ value was .242 and significant level was .000 ( $p<.01)$. Next, process innovation and hotel types were also two independent variables contributing to explain the variable of guest's return intention because of their relative large absolute standardized coefficients $(\beta=.238, \quad p<.01)$ and $(\beta=.212, p<.01)$, respectively. Marketing-focused innovation had the smallest effect to return intention of guests $(\beta=.124$, $p<.05)$. The adjusted $\mathrm{R}$ squared indicated that $30.2 \%$ of variance was explained by these six independent variables.

2) Perceived value and guest's return intention

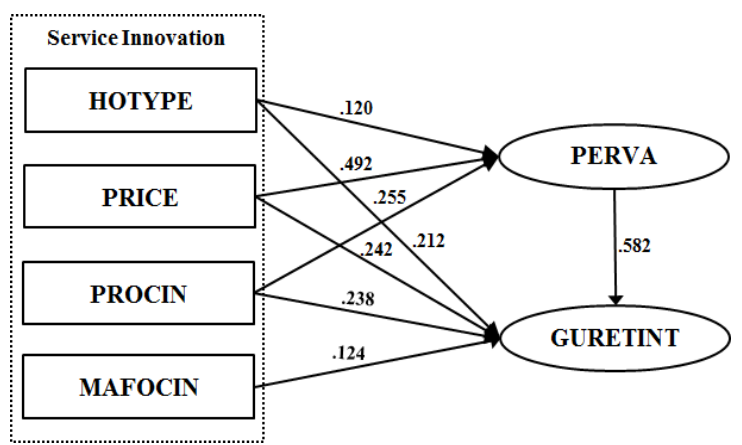

Note: All coefficients in the model were significant at the .005 level. Fig. 1. Path coefficients of GURETINT model.

To test the hypothesis 3 , a simple linear regression was conducted. It could be seen that perceived service value had positive significant relationship $(r=.582, p<.001)$ and provided direct effect on return intention of guests $(\beta=.582$ at Sig.=.000). As such it could be explained that when guests perceived the worth of service that they were offered, the hotel would be the first choice if they had chance to come 
back to visit Ho Chi Minh again.

The $\mathrm{R}$ squared value showed that there was $33.7 \%$ of variance of GURETINT variable could be explained by PERVA variable (see Fig. 1).

\section{E. Indirect Effects Service Innovation on GURETINT}

The indirect effect of an independent variable on the dependent variable through the intervening variable was the total product of the effects of that independent variable on the intervening variables and the effect of the intervening variable on the dependent variable of passenger satisfaction [26].

To test the hypothesis 4 , indirect effects were calculated by multiplication of Beta coefficient for direct effects among the associated variables. As a result, pricing innovation had the strongest indirect effect on the guest's return intention through perceived value of service with $\beta=.286$ (.492 multiplied by .582), followed by the innovation in process with $\beta=.148$ ( .255 multiplied by .582$)$ and the types of hotel factor with $\beta=.070$ (.120 multiplied by .582 ). The total indirect effect of the independent variables through the perceived value factor on guest's return intention was .504.

\section{$F$. Significance of the Indirect Effects}

Table IV showed the results of the bootstrapping method recommended by [26] to test the significance of indirect effects or mediations. The output provided the bootstrapped confidence intervals (at the 95\%). If there was a ZERO (0) lies within the interval range between the lower boundary (LL) and the upper boundary (UL), then we can conclude that, with $95 \%$ confidence, there was no mediation or indirect effect. On the other hand, if zero does not occur between the LL and the UL, then we can conclude that, with $95 \%$ confidence, the mediation or indirect effect was significant [27]. As can be seen in the output of Table IV, the indirect effects of HOTYPE, PROCIN, and PRICE on GURETINT through the mediation of PERVA were estimated to lie between .1123 (LL) and .2670 (UL); .2102 (LL) and .3645 (UL); and .2331 (LL) and .4041 (UL) with 95\% confidence, respectively. Because zero was not in the $95 \%$ confidence interval, we can conclude that the indirect effects of HOTYPE, PROCIN, and PRICE on GURETINT were indeed significantly different from zero at $p<.05$ (two tailed) and the mediation of PERVA in this study was true.

TABLE IV: THE SUMMARY OF PATH ANALYSIS

\begin{tabular}{lccccc}
\hline \hline \multirow{2}{*}{ Variables } & \multicolumn{3}{c}{ Casual effects } & \multirow{2}{*}{ LL } & UL \\
\cline { 2 - 4 } & Direct & Indirect & Total & & \\
\hline HOTYPE & .212 & .070 & .282 & .1123 & .2670 \\
PROCIN & .238 & .148 & .386 & .2102 & .3645 \\
PRICE & .242 & .286 & .528 & .2331 & .4041 \\
HOTYPE & .120 & --- & .120 & & \\
PROCIN & .255 & --- & .255 & & \\
PRICE & .492 & --- & .492 & & \\
MAFOCIN & .124 & --- & .124 & & \\
PERVA & .582 & --- & .582 & & \\
\hline Total & 2.265 & .504 & 2.769 & & \\
\hline \hline
\end{tabular}

\section{DisCUSSIONS AND RECOMMENDATIONS}

\section{A. Discussions}

From the above statistical analysis results, it is realized that
Pricing innovation, Process innovation, Hotel types and Marketing-focused innovation were four components that constitute the service innovation and provide effects on Perceived value and Return intention of the guest who stayed at luxury hotels.

Perceived value and guest's return intention were affected mostly by innovation in pricing. On the other hand, positive relationships between innovative pricing and two dependent variables were found from the Pearson correlation testing as well. For many years, various researches have been conducted to understand the dynamics of the hotel service industry in customer's perspective. Many researchers have highlighted different factors contributing to the way customer making their decision to stay at hotel, perceiving quality and value of the service. The result of this study is consistent with the findings of several related researches. The importance of price is considered as a key dimension in hotel selection [19]. Recently, reasonable price and cleanrooms were revealed to be two factors playing significant role for attracting American tourists [28]. Reference [29] moreover confirms that "accommodation value for money" is one of factors topping traveller's demands. It indicates that when a hotel offers reasonable price for its valuable services to guest and induces the guest to recognize that price is virtually justified by the service provided, the perceived service value would be achieved. This is because the guest is persuaded that payment is absolutely worth for what he received.

The second variable that also has positive correlation and significant influence on perceived value and guest's return intention was process innovation. This result supported by the contention that "innovation to be performed in services processes can provide an important contribution to the way the service is presented by employees" [14]. As noted before, process referred to the innovation created in processes of preparing and presenting the service to customers. In these processes, the service should be presented in accurate and high quality manner. The researchers also assert that. In service industry, especially in hospitality field, guests often become a part of the service process and always observe the details related to the preparation and presentation of the service. It could explain why process innovation covers elements that can be perceived directly by the guests. In other words, these elements, such as improvement of service delivery system, high qualification and effective performance of employees, can be clearly evaluated by them.

The statistical analyses showed that hotel type was also found to significantly influence perceived value of hotel service and it is an indispensable innovative practice that induces the guest to decide to return the hotel for the second time. The result of this study was recognized to have consistency with findings of a study relating to hospitality industry conducted by four researchers [7]. Their study discovered that hotel type was one of element of service innovation concept that contributed to the majority of choice of guest. Consequently, source of service innovation could be novel ideas of hotel types. This indicates that hoteliers should give focus on providing their hotels with the types being suitable for various purpose of staying of the guest. Moreover, it would also be good for hotel companies to plan the type of hotel to perform up based on their target 
customers. For example, hotels targeting business travellers who looking for conference hotels and hotels targeting holiday travellers who looking for boutique hotels or healthy-style hotels should look at different aspects of the type of hotel. Consequently, if such types of hotel meet the purpose of staying of the guest and make them distinguished from other hotels, the perceived value regarding the service will be affected positively.

Ultimately, a positive effect of marketing-focused innovation in perceived value and return intention of guests was confirmed. Reference [15] showed that innovation focusing on marketing as an indispensable factor contributing into effectiveness of service innovation practices, which agreed with the results of this study. In addition, it was evident to be consistent with a research confirming that marketing-focused innovation was a strategic factor to form up the scale of service innovation and a capability-based competitive advantage for a firm to develop its innovative service practices [30]. Admittedly, this factor was likely to have relatively effective application in hospitality industry of Vietnam context. The results of this study inferred that marketing-focused innovation did have an effect on guest's intention to return if they have chance to visit the hotel for a second time. However, how well the guest perceives service value was not directly affected by this factor, even though there was a positive correlation found between these factors. As such it could be explained by two reasons following. Firstly, marketing-focused innovation was probably inclined toward management rather than service producing. Therefore, it seemed to be hard for guests to be able to perceive it as a value in the service. How well hoteliers improved or renewed the promotional approaches were not substantially their concern. What is more, currently, almost all three-star and four-star hotel have not really focused and promoted marketing programs, market researches and effective service promotion. However, marketing focusing on innovation have moderate contribution in explaining if a guest intends to return the hotel and use its service again or not. It may be because a hotel develops appealing promotional programs and customers realize that they actually get what the advertising shown on website and brochures, they are encouraged to return back that hotel.

Although many previous studies have explored positive relationship between factors of service innovation and customer's choice as well as their value, there is no influence of innovation in information technology and customization of service on perceived service value are found on in this research.

From the results of Pearson correlation matrix and Beta coefficients, implementation of information technology in hotels have no effect to perceived value and guest return intention in spite of being positively associated with those dependent variables. While, this factor played a significant role of service innovation through the booking of hotel reservations via the Internet and provided an impact on guest's choice [7]. The explanation could be as following reasons. First of all, a hotel invested with modern information technology, such as available of multiple phones lines, fax machines, personal computers or tablets with network connection may not be easily perceived all the value if the guest by himself does not really have demand on using such equipment. As referred previously, majority of respondents in the study visited the hotel for their leisure time or holiday with their friends and family. This could be the reason to explain why the available of high information technology seems to be unnecessary to guests. Therefore, such guests perceive lowly about that. Some respondents gave their comments when they conducted this part of the questionnaires. Tourists who were going to travel with purpose of relaxing or discovering new countries usually did not expect the hotel they were staying equipped with high technology. A high-speed of wireless network allowing them searching location, food restaurant, market and so on was greatly appreciated. That is reason why perceived value and intention to return the hotel were not affected by use of information technology variables.

Recently, four and five-star hotels in Ho Chi City have been invested and developed by well-known corporations, so they are equipped with modern facilities and high technology. However, most of three-star hotels which occupying the largest percentage of hotel rank in the study find many difficulties in application or innovation information technology in management and performance the services as well. This lowers the perceived value from the guest staying at such rank of hotels.

Next, customization of services had no influence on service innovation and the two observed dependent variables. This result differed from findings of a research on related topic, which concluded that there was negative effect of customization of service on service innovation [6]. This could be explained through several reasons. Reference [31] showed that while it may seem profitable to add more products or features to the product mix, it may be too difficult to operationally implement the process. Therefore, this may contribute to explaining the non-relationship between the variables. Though, customization of service may be successful for the travelers in the US, it is not an important factors for travelers in Vietnam. This could be due to several other reasons and may also give rise to the possibility of a further research in the area.

\section{B. Recommendations for the Luxury Hotel Establishment}

After implementing and completing based on the objectives defined before, the findings of this study figured out several implications. The results from the statistical tests conducted showed that there were positive relationships between the factors of service innovation (including pricing innovation, process innovation, hotel types, use of information technology, marketing-focused innovation and customization of service) and perceived value of service with guest's return intention. Globalization, development of technology and higher standard of living have substantially changed the customer perception and expectations towards the hospitality industry, specially the hotel industry. It is really importance for hotel establishment to find out customer needs and deeply understand their preferences in order to create them high valuable service and convince them to visit the hotel for a second and more if they come back to Vietnam. 
It is apparent from this research that guests greatly valued for application in innovative aspects when staying at hotels. The outcome of this research showed that hotel industries could consider being more innovative in their service offerings to attract foreign tourists. In the regression analysis, pricing innovation, innovation in process and hotel types were found to significantly influence on perceived value. This indicates that hoteliers should give concern on providing their service being worthy with the guest payment. This means that it is highly important to induce the guest to perceive the value of service provided excess its price. Secondly, hotel establishment should put more efforts to the way of delivering services and form up training programs with aim of enhancing the employees' performance. Proficience in foreign languages and flexible problem-solving skills are indispensable elements for a qualified employee. Furthermore, it would also be good for hotels to plan the type of hotel to portray based on their target customers.

In spite of no effect on perceived value, investment in innovative marketing programs provides a direct effect on return intention of guests. Therefore, hoteliers should carefully project and carry out strategic promotional programs. Those are not enough, it is encouraged to be honest between their advertising on websites, brochures and their actual service offerings.

\section{CONCLUSION}

After application of the multivariate statistical techniques with factor analysis, standard multiple regression analyses, and path analysis, all the objectives of this study have been successfully achieved: firstly to identify what factors of service innovation affect perceived value and guest return intention ; secondly to measure direct and indirect effects of independent variables (pricing innovation, process innovation, hotel types, marketing-focused innovation) on dependent variable of return intention through perceived value; and thirdly provide recommendations for improving innovative practices in hotel industry market. Explanations and suggestions given were based on the review of the literature and the empirical findings of the study. For significant relationships aspect, bivariate correlations and Pearson correlation coefficients were employed determine the possibility linear relationship between two independent variables as well as between mediating variable and dependent variable in the model. Further, the direct and indirect effects of intention to return of guests were analyzed and discussed in order to obtain statistically significant evidence for all proposed research hypotheses. Thus, the implications of this study provide both theoretical and practical contributions to the field of hospitality management and development.

The empirical of the results showed that not all factors of service innovation have effects on the observed dependent variables of perceived value and return intention, even though use of information technology and customization of service were proved to strongly affect implementation of service innovation in the hotel industry by previous researches. This could be due to several objective reasons during study process that points out the need of further inquiry. The application of this model in other contexts with more meaningful statements for each observed variables are highly appreciated and encouraged for further researches. Last but not least, the concept of service innovation has been developed with many other dimensions like new marketable products and services, service products related, market related, service administrative. Therefore, this developed research framework could be expanded by investigating the effects of those factors on enhancing the intention to return the service of the guests.

\section{REFERENCES}

[1] M. Gasparotti, "The hotel market of Vietnam," presented at Asia Conference HOFTEL, Hyatt Regency, Da Nang, Vietnam, June 27-28, 2013.

[2] R. D. Reid and M. Sandler, "The use of technology to improve service quality," Cornell Hotel and Restaurant Administration Quarterly, vol. 33, no. 3, pp. 68-73, 1992.

[3] E. M. Rogers, Diffusion of Innovations, 5th Edition, New York: Free Press, 2003.

[4] J. A. Schumpeter, The Theory of Economic Development: An Inquiry into Profits, Capital, Credit, Interest and the Business Cycle, Harvard University Press, Cambridge (Mass), 1934.

[5] B. van Ark and P. den Hertog, "Service innovation, performance and policy: A review," Research Series No. 6, Ministry of Economic Affairs, The Hague, Netherlands, 2003.

[6] B. Veerakumaran, "The effect of service innovation and customer choices on customer value in the hospitality industry in Malaysia," M.A. Dissertation, Dept. Business \& Accountancy. Malays Univ., Malaysia, 2009.

[7] L. Victorino, R. Verma, G. Plaschka, and C. Dev, "Service innovation and customer choices in the hospitality industry," Managing Service Quality, vol. 5, no. 6, pp. 555-576, 2005.

[8] Binkley and Christina, "Hotels: big chains finally discover virtues of boutique hotels," Wall Street Journal, p. 1, January 1999.

[9] Hsu and J. S. Lee, "Empirical investigation of the roles of attitudes toward green behaviors, overall image, gender, and age in hotel customers eco-friendly decision-making process," International Journal of Hospitality Management, vol. 28, no. 4, pp. 519-528, 2009.

[10] N. Tzschentke, "Reasons for going green in serviced accommodation establishments," International Journal of Contemporary Hospitality Management, vol. 16, no. 2, pp. 116, 2004.

[11] C. W. L. Hart, "Mass customization: Conceptual underpinnings, opportunities and limits," International Journal of Service Industry Management, vol. 6, no. 2, pp. 36-45, 1995.

[12] P. den Hertog, "Knowledge-Intensive Business Services as Co-Producers of Innovation," International Journal of Innovation Management, pp. 491-528, 2000.

[13] D. J. Connolly, "Research methods: A guide to using the case study method to explore hospitality information technology phenomena," Information Technology in Hospitality, vol. 4, no. 1, pp. 23-46, 2005.

[14] H. N. Nasution and F. T. Mavondo, "Organisational capabilities: Antecedents and implications for customer value," European Journal of Marketing, vol. 42, no. 3-4, pp. 477-501, 2008.

[15] C. L. Wang and P. K. Ahmed, "The development and validation of the organizational innovativeness construct using confirmatory factor analysis," European Journal of Innovation Management, vol. 7, no. 4, pp. 303-313, 2004.

[16] A. A. Abdullah and M. H. Hamdan, "Internal success factor of hotel occupancy rate," International Journal of Business and Social Science, vol. 3, no. 22, pp. 199-218, 2012.

[17] L. L. Berry, V. Shankar, J. T. Parish, S. Cadwallader, and T. Dotzel, "Creating new markets through service innovation," Management Review, vol. 47, no. 2, pp. 54-63, 2006.

[18] K. Prasad and C. S. Dev, "Managing hotel brand equity," Cornell Hotel and Restaurant Administration Quarterly, vol. 41, no. 3, pp. 22-31, 2000.

[19] T. Lockyer, "The perceived importance of price as one hotel selection dimension," Tourism Management, vol. 26, pp. 529-537, 2005.

[20] S. Liozu. (September, 2012). Innovation in pricing. [Online] Available: http://www.pricingleadership.com/ innovation-in-pricing/

[21] V. A. Zeithaml, L. L. Berry, and A. Parasuraman, "The behavioral consequences of service quality," Journal of Marketing, vol. 60, no. 2, pp. 31-46, 1996. 
[22] H. N. Nasution and F. T. Mavondo, "Customer value in the hotel industry: What managers believe they deliver and what customer experience," International Journal of Hospitality Management, vol. 27, no. 2, pp. 204-213, 2008.

[23] A. Parasuraman, "Reflections on gaining competitive advantage through customer value," Journal of the Academy of Marketing Science, vol. 25, no. 2, pp. 154-161, 1997.

[24] R. Carr, P. Hellier, G. Geursen, and J. Rickard, "Customer repurchase intention: A general structural equation model," European Journal of Marketing, vol. 37, no. 11-12, pp. 1762-1800, 2003.

[25] B. G. Tabachnick and L. S. Fidell, Using Multivariate Statistics, 4th ed. New York: Harper Collins, 2001, ch. 13.

[26] J. K. Preacher and A. Hayes, "Asymptotic and resampling strategies for assessing and comparing indirect effects in multiple mediator models," Behavior Research Methods, vol. 40, no. 3, pp. 879-891, 2008.

[27] J. K. Preacher and A. F. Hayes, "SPSS and SAS procedures for estimating indirect effects in simple mediation models," Behavior Research Methods, Instruments and Computers, vol. 36, no. 4, pp. 717-731, 2004.

[28] K. J. Shanahan and M. R. Hyman, “An exploratory study of desired hotel attributes for American tourists vacationing in China and Ireland," Journal of Vacation Marketing, vol. 13, no. 2, pp. 107-118, 2007.

[29] A. Atkinson, "Answering the eternal question: what does the customer want?" The Cornell Hotel and Restaurant Administration Quarterly, vol. 39, no. 6, pp. 12-14, 1998.

[30] S. J. Hogan, G. N. Soutar J. R. McColl-Kennedy, and J. C. Sweeney, "Reconceptualizing professional service firm innovation capability:
Scale development," Industrial Marketing Management, vol. 40, pp 1264-1273, 2011.

[31] W. Skinner, "The focused factory," Harvard Business Review, vol. 52, no. 3, pp. 113-21, 1974.

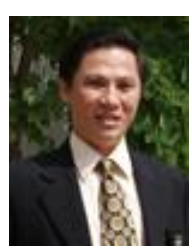

Mai Ngoc Khuong is a lecturer and researcher of School of Business Administration, International University, Vietnam National University, Ho Chi Minh City. He has bachelor degree in tourism and hospitality management, master of science degree in leisure, tourism and environment at Wageningen University, The Netherlands, and $\mathrm{PhD}$ degree in development management at School of Public Administration of the National Institute of Development Administration (NIDA), Bangkok, Thailand.

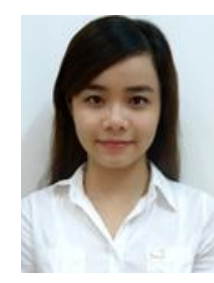

Tran Huong Giang is a research assistant of School of Business Administration, International University, Vietnam National University, Ho Chi Minh. 